\title{
PELATIHAN PENANAMAN PERILAKU KONSUMSI SINGKONG DAN RESPONSI MASYARAKAT
}

\author{
Masyhuri ${ }^{1}$, Nikmatul Khoiryah ${ }^{2}$, Sri Hindarti ${ }^{3}$ \\ ${ }^{1}$ Fakultas Pertanian Universitas Islam Malang \\ email: masyhuri003@gmail.com \\ ${ }^{2}$ Fakultas Pertanian Universitas Islam Malang \\ email: knikmatul3@gmail.com \\ ${ }^{3}$ Fakultas Pertanian Universitas Islam Malang \\ email: shindarti@yahoo.com
}

\begin{abstract}
ABSTRAK
Penanaman paradigma makanan berbasis singkong sedini mungkin pada kelompok sasaran dengan melalui demontrasi olah singkong dan analisis responsi kelompok sasaran pasca demontrasi olah singkong dengan deversifikasi produk Metode analisis pada deskriftif secara mendalam ini dilakukan dengan pendekatan participatory rapid appraisal dengan banyak tahap. Sedangkan untuk menjawab responsi kelompok digunakan analisis logit model. Hasil analisis menunjukkan bahwa (1) penanaman paradigma makanan berbasis singkong menunjukkan bahwa singkong bisa dibuat untuk makanan yang menarik, anak-anak dipersilahkan untuk memakan. Dari sinilah kemudian 'ajaran' (paradigma) ditanamakan kepada anak-anak (mereka) makan adalah 'apa saja' tidak hanya nasi dan makan adalah untuk ibadah. Oleh karena itu perlu dianalisis 'makan' dari aspek spiritual guna mengembangkan ilmu pengetahuan yang lebih luas dan integratif; (2) analisis responsi kelompok sasaran pasca demontrasi olah singkong dengan deversifikasi produk. Hasil analisis dari lima variabel tersebut mempunyai pengaruh yang negatif, yaitu umur kelompok sasaran, jumlah anggota keluarga, pendidikan, konsumsi singkong per hari. Sedangkan pendapatan mempunyai pengaruh positif. Dari hasil pelaksanaan program ini disarankan bahwa meskipun tidak mudah dalam melakasanakan penanaman paradigma, tetapi minimal ada yang memulainya, sebab paradigma sesuatu tindakan tang berupaya untuk merubah perilaku - maka dari itu perlu waktu yang cukup lama. Atas dasar itulah, maka pada program pengabdian ini disarankan beberapa hal, yaitu semua pihak diharapkan mempunyai kontribusi yang positif terhadap upaya ketahanan pangan melalui teori 'makan tidak hanya nasi' utamanya pada anak sedini mungkin.

Kata Kunci : prilaku, konsumsi, singkong, respon dan masyarakat.
\end{abstract}

\section{PENDAHULUAN}

Singkong (Manihot utilisima sp.) merupakan salah satu komoditas pengganti (substitut) beras yang cukup dekat, karena singkong mempunyai potensi pasar yang cukup besar, yang diindikasikan oleh berbagai 
makanan non beras dengan bahan bakunya dari singkong. Bahkan komoditas ini tidak jarang dikonsumsi langsung, baik bentuk rebusan atau gorengan. Hasil survei awal menunjukkan bahwa permintaan setiap satu penjual membutuhkan sekitar 20-35 kg singkong mentah dengan deversifikasi produk sebanyak 4 jenis makanan siap saji, dan habis terjual dalam kurun waktu 4-5 jam.

Kenyataan ini dapat dijadikan sebagai indikator potensi permintaan singkong cukup besar, belum lagi untuk produk lainnya seperti tape singkong, tepung singkong, kue singkong, dan lainnya. Akan memunculkan suatu permasalahan baru bagi para produsen makanan yang bahan bakunya dari singkong, permasalahan ini akan semakin berat jika produktivitas petani produsen singkong menurun.

Secara regional rata-rata produksi singkong sebesar 159,48 kw/ha dengan daerah sentra produksi adalah Kediri dan Banyuwangi yang berturut-turut rata-rata produksi 191,10 dan 193,21 kw/ha. Daerah perkotaan yang menghasilkan singkong pada lahan pekarangan adalah Kediri dengan rata-rata produksi 144,34 kw/ha, Malang sebesar 138,76 $\mathrm{kw} / \mathrm{ha}$, Surabaya $145,00 \mathrm{kw} / \mathrm{ha}$, dan kota Batu rata-rata produksi singkong sebanyak 133,60 kw/ha. Namun, masih terjadi produksi singkong yang tidak berimbang (unbalance) antara wilayah yang membutuhkannya dengan wilayah yang menghasilkannya.

Oleh karena itu, akan dilakukan pengabdian dengan entry point dukungan program penanaman paradigma makanan berbasis singkong sedini mungkin pada kelompok sasaran dengan melalui demontrasi olah singkong dan melakukan analisis responsi kelompok sasaran pasca demontrasi olah singkong dengan deversifikasi produk.

\section{TUJUAN PENGABDIAN}

1. Penanaman paradigma makanan berbasis singkong sedini mungkin pada kelompok sasaran dengan melalui demontrasi olah singkong

2. Analisis responsi kelompok sasaran pasca demontrasi olah singkong dengan deversifikasi produk

\section{MEKANISME PENGABDIAN}

Dilakukan dengan program aksi dengan pendekatan participatory rapid appraisal dengan banyak tahap. Sedangkan untuk menjawab responsi kelompok digunakan analisis logit model.

\section{HASIL PELAKSANAAN PROGRAM DAN PEMBAHASAN}

A. Analisis Penanaman Paradigma Makanan Berbasis Singkong Sedini Mungkin pada Kelompok Sasaran dengan Melalui Demontrasi Olah Singkong

Hasil pelaksanaan ini pada kelompok sasaran dianalisis dengan kajian kualitatif, khususnya pada poin penanaman paradigma 'makanan 
singkong'. Hal yang mendorong melakukan makanan pokok masyarakat Indonesia adalah beras sehingga jika mereka ditayakan 'pakahah anda sudah makan?', maka jawabannya pasti belum makan. Berapapun jumlah makanan dan jenis makanan yang dimakan oleh seseorang jika dari non beras, maka jawabannya dapat ditebak, yaitu 'belum makan'.

Peristiwa terjadi saat musim haji tahun 2006, yaitu katering yang dikirim oleh petugas terlambat akibat kemacetan lalu lintas di seputaran wilayah wuquf. Banyak haji dari Indonesia diberitakan 'tidak makan 2 hari'. Ternyata yang terjadi 'tidak makan' itu adalah tidak makan nasi, padahal ada pihak (sebutan sabilillah) yang selalu menyumbangkan/membagikan bungkusan yang isinya roti, buah dan minuman.

Atas dasar fenomena di atas, maka program ini akan mengungkapkan paradigma tentang makan, ditinjau dari berbagai aspek. Menurut Zaitunah Subhan (2010) mengatkan bahwa "paradigma (paradigm) dapat ditafsirkan bermacam-macam sesuai dengan sudut pandang masing-masing orang. Paradigma ibarat sebuah jendela tempat orang mengamati dunia luar, tempat orang bertolak untuk menjelajahi dunia dengan wawasannya (world-view). Secara umum, paradigma dapat diartikan sebagai seperangkat kepercayaan atau keyakinan dasar yang menuntun seseorang dalam bertindak pada kehidupan sehari-hari".

Berkaitan dengan inti masalah paradigma kata kunci definisi di atas "tentang kepercayaan dan keyakinan untuk bertindak sehari-hari", maka lambat laun 'kebiasaan makan pasti nasi' akan berubah. Perubahan ini tentunya tidak semudah membalikkan tangan karena menyangkut perilaku sehingga membutuhkan waktu untuk menuju perubahan tersebut.

Deversifikasi kemasan dan pola makan menjadi menarik dan laku dijual tetapi jika pada kemasannya tidak menarik, maka sulit laku untuk dijual. Tujuan kemasan adalah konsumen diharapkan tertarik atas makanan tersebut sehingga 'apa pun yang dimakan non beras' orang akan menjawab ditanya 'apa sudah makan?' jawabannya adalah 'sudah'. Karena itulah peranan lbu rumah tangga untuk menanamkan paradigma makan ini cukup penting - hasil pelaksanaan pengabdian dengan olah singkong pada berbagai bentuk makanan adalah sebagai salah satu upaya untuk menuju pada penanaman paradigma singkong.

Deversifikasi olah produk bahan baku singkong dari program ini kelompok sasaran utamananya adalah tingkat kaman kanak-kanak yang didampingi masing-masing dari lbu wali murid. Keterlibatannya dimaksudkan untuk membantu dalam aksi riset ini, sebab itulah efektifitas diharapkan dapat terwujud karena komunikasi terbangun dari pihak-pihak yang berkompeten.

Keterlibatannya ibu wali murid disamping untuk membantu komunikasi murid-guru-wali murid-peneliti juga semua pihak diajak untuk melakukan teknologi tepat guna oleh makanan berbahan singkong (ini jangka pendeknya) pada satu sisi. Disisi yang lain, jangka panjangnya wali murid 
dan murid adalah dua pihak kelompok sasaran yang selalu berinteraksi. Pesan peneliti pada ibu wali murid adalah 'tanamakan kepada anak-anak bahwa makan itu tidak hanya dari nasi saja tetapi non nasi-pun jika sudah kita makan, maka termasuk juga itu sudah makan'.

Implikasi yang dapat diambil dari program aksi para ibu rumah tangga guna 'meminimisasi' paradigma 'kalau makan adalah dengan nasi' sebagai berikut: (i) ilmu pelatihan teknologi tepat guna. Teknologi tersebut dikhususkan pada cipta olahan pangan berbahan dasar hortikultural unggulan lokal dan pengemasan; (ii) makanan merupakan kebutuhan pokok manusia yang dilakukan secara terus menerus dan dibutuhkan dalam kehidupan sehari-hari (tidak hanya beras/nasi saja), makanya perlu dilakukan perubahan dengan diversifikasi dan pola makan; (iii) makanan dikemas dalam bentuk yang beranake ragam baik pada makaan ringan serta sayur dan buah-buahan; (iv) kue maupun makanan kecil lainya bahannya juga berasal dari beras sebenarnya juga makan pokok bahkan perkembangan sekarang bahan bakunya tidak dari beras; (v) pembuatan kue tidak harus menggunakan beras; (vi) inovatif dan kreasi dari puding saja bisa di buat dengan bahan sayuran dan buah; (vii) pemanfaatan bahan-bahan hortikultura yang murah dan mudah di dapat di sekitar kita dalam berivovasi membuat jajanan atau makanan. Selain murah harganya dan mudah di dapat, bahan hortikultura juga mempunyai kandungai gizi yang besar.

Makanan pokok di Indonesia adalah nasi akan menjadi kendala yang serius dalam menubah paradigma 'makan adalah nasi'. Namun dalam pendukung adanya program ketahanan pangan - meskipun adanya kendala yang esensi tetapi dengan penelitian ini paling tidak dimulai dari sekarang minimal menjadi bahan renungan dan pemikiran bagi pembaca dan/atau para generasi penerus. Karena itulah singkong dan nasi adalah sebagai bahan pangan substitusinya (penggantinya) cukup dekat.

Generasi sekarang yang dilakukan Dosen Teknologi Pangan Politeknik Negeri Lampung Beni Hidayat "sepenggal anekdot tentang nasi menjadi gambaran umum kebiasaan makan orang Indonesia. Anekdot itu adalah "belum benar-benar makan bila belum makan nasi". Aksis riilnya adalah membuat beras siger dari singkong yang persis seperti beras asli guna meminimisasi ketergantungan masyarakat Indonesia pada nasi hanya masalah psikologis sehingga lapar yang dirasakan karena tidak makan nasi, walau sudah makan singkong, jagung atau sagu, juga karena masalah psikologis. Karena itu, Beni mengembangkan beras dari singkong yang diberi nama beras siger. Bentuk singkong yang dibuat seperti butiran beras bisa mengobati lapar psikologis yang dialami masyarakat karena merasa makan nasi. Proses pembuatan beras ini hampir sama dengan tiwul, tapi menggunakan banyak teknologi guna menghasilkan tiwul yang mendekati bentuk seperti beras. Beras singkong ini berwarna putih dan bentuknya bulat kecil, sedikit lebih besar dibandingkan gula pasir. Selain 
itu beras siger tidak berbau apek seperti bau tiwul, masa simpannya juga lama hingga 6 bulan".

Menteri Perdagangan Gita Wirjawan sebagai makanan pokok alternatif untuk menggantikan beras adalah singkong. Banyak sekali nilai strategis yang dimiliki singkong bila berhasil dijadikan makanan pokok pengganti beras. Selain telah menjadi makanan pokok ketiga setelah beras dan jagung, singkong merupakan salah satu tanaman ubi-ubian yang sangat mudah ditanam di Indonesia. Bahkan, dari sisi kandungan, singkong juga mempunyai kadar Karbohidrat yang lebih tinggi dengan nasi putih.

Upaya dari penelitian untuk mendukung ketahanan pangan dengan melakukan olah singkong dengan berbagai macam bentuk. Demonstrasi yang dilakukan adalah mengajak kepada kelompok sasaran untuk melakukan olah singkong menjadi aneka makanan yang menarik, siap saji dan siap makan. Bahan baku yang disiapkan dengan pendekatan partisipatori yang dibentuk dalam kelompok dan masing-masing kelompok terdiri dari 4-5 anak yang didampingi oleh masing-masing wali (ibu) anak.

Model dan cetakannya disediakan dan masing-masing kelompok dibebaskan untuk menentukan bentuk olahannya. Fokus sasarannya adalah anak-anak, ternyata mereka mempunyai daya motorik terhadap makanan cukup baik yang diindikasikan dengan variasi bentuk makanan cukup banyak. Kemudian dari hasil olahan mereka ditunjukkan bahwa singkong bisa dibuat untuk makanan yang menarik, anak-anak dipersilahkan untuk memakan. Dari sinilah kemudian ajaran/paradigma ditanamakan kepada anak-anak (mereka) makan adalah 'apa saja' tidak hanya nasi dan makan adalah untuk ibadah. Oleh karena itu perlu dianalisis 'makan' dari aspek spiritual guna mengembangkan ilmu pengetahuan yang lebih luas dan integratif.

Sejak 14 abad yang lalu Nabi Muhammad SAW memberikan ajaran bahwa "perubahan manusia yang paling jelek dalam memenuhi bejana adalah memenuhi perut". Pada zaman sekarang, bahaya tersebut diakui dengan adanya berbagai penyakit berbahaya yang disebabkan oleh sikap berlebihan dalam mengkonsumsi makanan. Pengakuan ini diketahui setelah dilakukan berbagai riset yang mendalam dalam bidang kedokteran.

Kebutuhan makanan masing-masing orang dari waktu ke waktu berbeda-beda. Namun, secara umum ada porsi kebutuhan makanan yang sama diatara mereka yang dibutuhkan orang dewasa untuk menjaga kegiatan utama badan, seperti detak jantung, peredaran darah, pernapasan, pencernaan, kencing, otot, dan beberapa kegiatan penting demi kelangsungan hidup, juga kebutuhan ion-ion pada otot.

Rasulullah Saw mengajarkan perbedaan kebutuhan ini. Penyebutuhan 'beberapa suap nasi untuk menguatkan tulang' merupakan ungkapan untuk mengiaskan porsi seimbang yang dibutuhkan manusia, mungkin juga mengkonsumsi makanan lebih sedikit jika melihat pembagian energi menjadi dua; (i) energi yang secara langsung dihasilkan dari sari pati gizi, 
dan (ii) kemampuan yang dihasilkan dari molekul yang tersimpan dalam susunan adenosina trifosfat (ATP) dan yang lainnya. Ini merupakan yang luar biasa. Dengan begitu, menjadi jelaslah mengapa para pejuang pada zaman sahabat kuat berperang. Ternyata, salah seorang diantara mereka cukup mengkonsumsi tambahan segenggam kurma.

Bagi kaum muslimin, jangan pernah mengkonsumsi makanan seperti ini kecuali sedang mengerjakan pekerjaan berat, tidak mampu lagi menahan nafsu, atau dalam keadaan darurat yang mengaharuskan mengkonsumsi porsi makanan seperti itu. Bahkan kalau bisa, lebih sedikit dari porsi tersebut dalam rangka menerapkan nasihat Nabi Muhammad Saw. Ketika kaum muslimin menjalankan ajaran hadist ini, dia mendapatkan pahala, karena mengikuti Nabi Muhammad Saw. Disamping itu pada akhirnya menghindarkannya dari kelebihan berat badan serta penyakit dan bahaya obesitas.

Keseimbangan gizi adalah merupakan kesepakatan yang sangat disetujui oleh para ahli gizi. Berikut ini batasan makan dan jenisnya yang dibutuhkan manusia berdasarkan aktivitas dan pekerjaannya: (i) gizi harus terdiri dari unsur-unsur utama, seperti karbohidrat, protein, lemak, vitamin, mineral dan air; (ii) porsi karbohidrat untuk satu hari sekitar $60 \%$, protein $15 \%$ dan lemak 25\%; (iii) ukuran kalori yang sesuai untuk seseorang berdasarkan pekerjaan terbagi dari tiga unsur. Sebagai penutup pada sub bab ini, etika makan dan bahaya kenyang (disamping hahaya terhadap makanan tidak halal karena perolehannya akan datang ular berbisa dari luar kuburan) ada enam; (i) badan berat dan akan melemahkan tubuh; (ii) keras hati; (iii) hilangny kecerdasan; (iv) melemahnya tubuh untuk ibadah dan mencari ilmu; (v) menyebabkan kantuk dan (vi) memperkuat dorongan syahwat dan membantu balatentara setan.

Singkong yang merupakan komoditas yang dekat dengan nasi mempunyai kandungan karbohidrat. Dalam per 100 gram singkong itu meliputi: Kalori $121 \mathrm{kal}$, Air 62.50 gram, Fosfor 40.00 gram, Karbohidrat 34.00 gram, Kalsium 33.00 miligram, Vitamin C 30.00 miligram, Protein 1.20 gram, Besi 0.70 miligram, Lemak 0.30 gram, Vitamin B1 0.01 miligram. Sementara pada kulit batangnya mengandung Tannin, Enzim Peroksidase, Kalsium Oksalat, dan Glikosida. Tanama ini berada di iklim tropis khsusnya di Indonesia dan tanaman ini sangat kebal dari serangan hama penyakit.

\section{B. Analisis responsi kelompok sasaran pasca demontrasi olah singkong dengan deversifikasi produk}

Variabel yang terlibat untuk mendeteksi pada kelompok sasaran dalam menanamkan paradigma 'makan tidak hanya nasi' sedini mungkin adalah variabel umur, jumlah anggota keluarga, pendidikan, pendapatan (income) dan konsumsi singkong per hari. Hasil analisis dari lima variabel tersebut mempunyai pengaruh yang negatif sedangkan pendapatan 
mempunyai pengaruh positif, yang menunjukkan bahwa responsi masyarakat pada konsumsi juga meningkat, sedangkan tanda yang negatif menunjukkan sebaliknya. Faktor lainnya adalah umur, artinya pengaruh yang negatif, berarti bertambahnya umur menyebkan responsi pada konsumsi singkong semakin berkurang. Hasil analisis tersebut mengindikasikan bahwa masyarakat Indonesia 'dengan bertambahnya usia ada kecendrungan menambah dalam konsumsi selain singkong khususnya beras'. Disamping itu juga didorong oleh factor jumlah anggota keluarga, Pendidikan dan tingkat pendapatan rumah tangga. pendapatan (income) juga mempunyai pengaruh secara negatif, artinya bertambahanya pendapatan masyarakat menyebabkan berkurangnya konsumsi singkong. Interpretasi ini menguatkan penjelasan pada variabel jumlah anggota keluarga, artinya anggota keluarga yang mempunyai status sosial lebih baik menyebabkan berkurangnya konsumsi singkong dengan alasan, mereka mempunyai kekuatan untuk membeli beras.

"Mind set masyarakat secara perlahan harus diubah, karena sebenarnya, singkong jika diolah menjadi bahan makanan kreatif akan menghasilkan nilai jual yang sangat tinggi. Presiden Soekarno ketika konsumsi singkong dan umbi-umbian lainnya sempat mencapai angka konsumsi 30 kilogram per kapita per tahun. Perlahan namun pasti konsumsinya semakin menurun seiring dengan berbagai kebijakan yang mengarah untuk mengkonsumsi beras.

Hasil analisis menunjukkan pengaruh yang negatif, maka sehariharinya masyarakat masih mengkonsumsi nasi dan semakin jauh dari konsumsi singkong. Dengan ini memberikan indikasi bahwa konsumsi nasi sulit untuk dilepas dari konsumsi masyarakat Indonesia, menurut mentan bahwa konsumsi pangan pokok beras per kapita di Asia Tenggara dapat dikatakan masih tinggi. Saat ini konsumsi beras di Indonesia 316 gram per kapita per hari, padahal cukup dengan 275 gram per kapita per hari. Sementara itu, konsumsi umbi-umbian hanya 40 gram per kapita per hari, dari jumlah ideal 100 gram per kapita per hari.

Fenomena di atas menyebabkan tuntutan terhadap kebutuhan beras semakin meningat, tentunya pihak yang meras mempunyai tanggungjawab pada kebutuhan ini adalah pemerintah (government). Jangka pendeknya pemerintah selalu memantau kebutuhan dan ketersediaan beras pada masyarakat, satu sisi. Disisi lain, pemerintah melakukan deversifikasi pangan non beras, seperti pada ubi-ubian, singkong, dan jenis lainnya non beras. Pola pikir, 'makan' adalah nasi diupayakan untuk dirubah meskipun membutuhkan waktu cukup lama, namun minimal telah dimulainya dari sekarang. 


\section{KESIMPULAN}

Hasil pembahasan di atas dapat disimpulakn:

1. Penanaman paradigma makanan berbasis singkong sedini mungkin pada kelompok sasaran dengan melalui demontrasi yang dilakukan adalah mengajak kepada kelompok sasaran untuk melakukan olah singkong menjadi aneka makanan yang menarik, siap saji dan siap makan. Bahan baku yang disiapkan dengan pendekatan partisipatori yang dibentuk dalam kelompok dan masing-masing kelompok terdiri dari 4-5 anak yang didampingi oleh masing-masing wali (ibu) anak. Model dan cetakannya disediakan dan masing-masing kelompok dibebaskan untuk menentukan bentuk olahannya. Fokus sasarannya adalah anak-anak, ternyata mereka mempunyai daya motorik terhadap makanan cukup baik yang diindikasikan dengan variasi bentuk makanan cukup banyak. Kemudian dari hasil olahan mereka ditunjukkan bahwa singkong bisa dibuat untuk makanan yang menarik, anak-anak dipersilahkan untuk memakan. Dari sinilah kemudian ajaran/paradigma ditanamakan kepada anak-anak (mereka) makan adalah 'apa saja' tidak hanya nasi dan makan adalah untuk ibadah. Oleh karena itu perlu dianalisis 'makan' dari aspek spiritual guna mengembangkan ilmu pengetahuan yang lebih luas dan integratif.

2. Analisis responsi kelompok sasaran pasca demontrasi olah singkong dengan deversifikasi produk. Hasil analisis dari lima variabel tersebut mempunyai pengaruh yang negatif, yaitu umur kelompok sasaran, jumlah anggota keluarga, pendidikan, konsumsi singkong per hari. Sedangkan pendapatan mempunyai pengaruh positif.

\section{SARAN}

Meskipun tidak mudah dalam melakasanakan penanaman paradigma, tetapi minimal ada yang memulai sebab paradigma sesuatu tindakan yang berupaya untuk merubah perilaku - maka dari itu perlu waktu yang cukup lama. Atas dasar itulah, maka pada program ini disarankan bahwa Semua pihak diharapkan mempunyai kontribusi yang positif terhadap upaya ketahanan pangan melalui teori 'makan tidak hanya nasi' - utamanya pada anak sedini mungkin.

\section{PUSTAKA}

Masyhuri, M.,(1996). Pola Alokasi Tenaga Kerja Keluarga Dalam Menunjang Perekonomian Rumah Tangga pada Daerah Pengembangan Kawasan Industri. DIKTI. No.116/P2IPT/DPPM/LITMUD/1996. ,(1998). Studi Kelayakan Mendirikan Cold Storage (CS) dan Milk Treatmen (MT) pada Beberapa Koperasi Unit Desa 
(KUD) Produsen Susu Sapi Perah di Kab. Malang. DIKTI. No.130/P21PT/DPPM/98 LITMUD/V/1998.

,(1998). Pemberdayaan Masyarakat Pedesaan pada Industrialisasi Pedesaan sebagai Upaya Menanggulangi Kemiskinan dalam Rangka Menghadapi Era Globalisasi. Penelitian Hibah Bersaing, DIKTI. No.75/P21PT/PHB/ VII-1/V/1999. (tahun I).

,(1999). Pemberdayaan Masyarakat Pedesaan pada Industrialisasi Pedesaan sebagai Upaya Menanggulan gi

Kemiskinan dalam Rangka Menghadapi Era Globalis asi. PHB. DIKTI:No.044/P2IPT/HB/VII-2/1999. (tahun I dan II).

,(2000). Usaha Pembentukan "koperasi Tani" pada Masyarakat Pedesaan Guna Menuju Masyarakat Mandiri sebagai Sarana untuk Pemberdayaan Usahatani PALAGUNG. PDM, DIKTI. No.089/P21PT/ $\mathrm{DM} / \mathrm{VI} / 2000$.

,(2002). Analisis Perencanaan Sumberdaya Pertanian Yang

Optimal. Disertasi S-3. Surabaya: Program Studi Ilmu Ekonomi Pembangunan PPS UNAIR Surabaya.

,(2003). Studi Potensi Wilayah Poncokusumo Untuk AGRO

ECO TURISM Dari Aspek Prasarana dan Produk

Unggulan Wilayah. BALITBANG Kab. Malang. Nomor

SPK/SPMK: 074/282/ KEP/421.203/2003.

,(2008). Optimalisasi Distribusi Singkong yang Berimbang

(balance) Guna Mendukung Ketahanan Pangan. PHB:

DP2M Ditjen Dikti Depdiknas, No Kontrak: 231/SP2H/PP/DP2M/III/2008. Tgl. 6 Maret 2008 (tahunI).

,(2010). Optimalisasi Distribusi Singkong yang Berimbang (balance) Guna Mendukung Ketahanan Pangan. Dibiayai DP2M Ditjen Dikti Depdiknas. No Kontrak: 110/SP/2H/PP/DP2M/ III/2010.

,(2011). Optimalisasi Distribusi Singkong yang Berimbang (balance) Guna Mendukung Ketahanan Pangan. Dibiayai DP2M Ditjen Dikti Depdiknas. No Kontrak: 0080/SP2H/PP/K7/KL/IV/2011.

,(2012). Optimalisasi Distribusi Singkong yang Berimbang (balance) Guna Mendukung Ketahanan Pangan. Dibiayai 
DP2M Ditjen Dikti Depdiknas. No Kontrak: 0032/SP2H/PP/K7/KL/II/2012. 9 Pebruari 2012.

-,(2013). Model Pemanfaatan Lahan Marginal (Pematang;

Galengan) Dan/Atau Lahan Pekarangan Pasca

Diberlakukan Distribusi Singkong Yang Optimal Guna

Mendukung Peningkatkan Akses Rumah Tangga Tani

Pada Cadangan Pangan Yang Berkelanjutan

(Sustainable). Malang: LPPM Unisma, Laporan

Penelitian Stranas. No. Kontrak: SP023.041.673453/2013.(13

September 2013).

,(2013). Model Pemanfaatan Lahan Marginal (Pematang;

Galengan) Dan/Atau Lahan Pekarangan Pasca

Diberlakukan Distribusi Singkong Yang Optimal Guna

Mendukung Peningkatkan Akses Rumah Tangga Tani

Pada Cadangan Pangan Yang Berkelanjutan

(Sustainable). Malang: LPPM Unisma, Laporan

Penelitian Stranas. Tahun I-No. Kontrak:

SP023.041.673453/2013.(13 September 2013).

,(2014). Model Pemanfaatan Lahan Marginal (Pematang;

Galengan) Dan/Atau Lahan Pekarangan Pasca

Diberlakukan Distribusi Singkong Yang Optimal Guna

Mendukung Peningkatkan Akses Rumah Tangga Tani

Pada Cadangan Pangan Yang Berkelanjutan

(Sustainable). Malang: LPPM Unisma, Laporan

Penelitian Stranas. Tahun II-No.Kontrak:

016/SP2H/P/KM7/2014 tanggal 3 April 2014.

Masyhuri, M.,(2007). Model Pengembangan Sektor Pariwisata Alam (Agro Eco Tourism). AGRITEK - Jurnal Terakreditasi Nasional.ISSN 0852 5426. HALAMAN 960-969.

,(2007). Analisis Deskripsi Permintaan Dan Penawaran

Sektor Pariwisata dan Lingkungan. AGRITEK - Jurnal

Terakreditasi Nasional. ISSN 0852-5426 HAL.;197-202. NOPEMBER-EDISI KHUSUS.

,(2015). optimalization of cassava distribution and marginal area usage for supporting food endurance. International journal of Applied Engineering Research Editor-in-Chief. Prof.Ir.Dr.Mohd Sapuan Salit. RIP Reseacrh India Publications http://www. Ripublication.com. VOL.10 NUMBER 1, 2015.ISS 0973-4562.Username:

IJAER.Pasward:IJAER*665\#RIP.ter-indeks SCOPUS. 